\title{
ISOLATION AND CHARACTERIZATION OF A SURFACTANT-STABLE PROTEASE FROM HALOPHILIC BACTERIA Chromohalobacter Japonicus BK-AB18
}

\author{
DWI ISYANA ACHMAD, IHSANAWATI and RUKMAN HERTADI* \\ Biochemistry Research Division, Faculty of Mathematics and Natural Sciences, \\ Bandung Institute of Technology, Bandung 40116 Indonesia \\ *E-mail: rukman@chem.itb.ac.id
}

Accepted 23 April 2020, Published online 6 July 2020

\begin{abstract}
The protease from Chromohalobacter japonicus BK-AB18 was produced by growing bacteria in a LB medium containing $5 \%$ casein and $5 \% \mathrm{NaCl}$. The crude protease was partially purified by three levels of ammonium sulfate concentration (ranges of $0-70 \%, 70-75 \%$ and $75-80 \%$ ) and the highest specific activity was exhibited in the range of $75-80 \%$. The enzyme has a relative molecular weight of $65 \mathrm{kDa}$. The protease in this fraction had the highest activity in the following optimum conditions: $7.5 \% \mathrm{NaCl}$, a $\mathrm{pH}$ of 9.0 and a temperature of $45^{\circ} \mathrm{C}$. The activity of the enzyme at the optimum $\mathrm{pH}$ and temperature was enhanced by the addition of a $\mathrm{Ca}^{2+}$ ion, but its activity was significantly inhibited by EDTA, hence this enzyme is included as metalloenzyme. Interestingly, the protease activity increased when exposed to a concentration of $0.01 \%$ and $0.05 \%$ SDS, and was relatively stable in this solution up to a concentration of $10 \%$. It is thus demonstrated that $C$. japonicus BK-AB18 is a potential source to produce extracellular protease that can be applied in the surfactant/detergent industry.
\end{abstract}

Key words: Chromohalobacter japonicus, protease, halophilic, surfactant-stable

\section{INTRODUCTION}

Proteases are hydrolysis enzymes that cleave proteins into shorter peptides (Motyan, et al., 2013). Proteases represent the most used industrial enzyme applied in various types of industries, such as the manufacture of surfactants and detergents. These industries require proteases that have a high activity and good performance in various conditions, from mild to extreme, such as in detergents and also in conditions of high salinity (Rao et al., 1998). In this study, we are interested in exploring the potential of protease produced by local halophilic bacteria in Indonesia. Halophilic bacteria have the ability to live in extreme conditions, and the biomolecules of these bacteria have good stability and unique character. Bacillus sp., Halobacillus karajensis, Salicomarasensis sp. IC10 and Chromohalobacter sp. TVSP101 are halophilic bacteria that produce extracellular proteases (Rao et al., 1998; Vidyasagar et al., 2009) showing unique biochemical and biophysical properties. The extracellular protease isolated from halophilic bacteria Bacillus sp. and

\footnotetext{
* To whom correspondence should be addressed.
}

Bacillus mojavensis A21 has been reported to be stable in both SDS solutions and detergent solutions, therefore having potential to be applied in the surfactant/detergent industry (Gupta et al., 2002; Haddar et al., 2009).

In the present study, we attempted to explore the potential of five halophilic bacteria isolated from the mud crater Bledug Kuwu in Purwodadi, Central Java, Indonesia (Asy'ari et al., 2014). We used four isolates of the Halomonas genus of bacteria: Halomonas elongata BK-AB8, Halomonas meridian BK-AB4, Halomonas elongata BK-AG18 and Halomonas eurihalina BK-AB15, as well as the isolate Chromohalobacter japonicus: BK-AB18 (Asy'ari et al., 2014). In this study, we reported that C. japonicus BK-AB18 is the most potent among halophilic bacteria producing protease that is stable in surfactant solutions.

\section{MATERIALS AND METHODS}

\section{Chemicals}

Ammonium sulfate, Luria-Bertani (LB) medium, $\mathrm{NaCl}$, SDS, Tris- $\mathrm{HCl}$ buffer, $\mathrm{KCl}, \mathrm{MgCl}_{2}$, various 
metal ions (EDTA, $\mathrm{Ca}^{2+}, \mathrm{Cu}^{2+}, \mathrm{Fe}^{3+}, \mathrm{Mg}^{2+}, \mathrm{Ni}^{2+}$ and $\mathrm{Zn}^{2+}$ ions).

\section{Bacterial cultivation}

The medium used for the cultivation of bacteria was Luria-Bertani (LB) liquid medium containing $1 \%$ tryptone, $0.5 \%$ yeast extract and $10 \% \mathrm{NaCl}$. Bacterial isolates were transferred into $5 \mathrm{ml} \mathrm{LB}$ medium and incubated at $150 \mathrm{rpm}$ at $37^{\circ} \mathrm{C}$ in an incubator shaker for 24 hours.

\section{Screening of proteolytic activity}

The screening for proteolytic activity was assayed by a modification of agar diffusion method using a medium containing $2 \%$ bacto agar and $2 \%$ casein (Sneha et al., 2014). After incubation for 24 hours, the culture was centrifuged at $9.820 \times g$ for 10 minutes. Twenty microliters of free-cell supernatant from each culture was placed on paper discs on agar plates and then incubated at $37^{\circ} \mathrm{C}$. The casein hydrolysis detected a clean zone in an area around the paper disc as an indication of proteolytic activity.

\section{Production and purification of the protease}

A protease production medium containing $3 \mathrm{gm} /$ 1 yeast extract, $5 \mathrm{gm} / 1 \mathrm{KCl}, 5 \mathrm{gm} / 1$ casein, $10 \mathrm{gm} / 1$ $\mathrm{MgCl}_{2}, 10 \mathrm{gm} / 1$ peptone and $5 \% \mathrm{NaCl}$ was used. A measure of $1 \%$ of the culture was transferred into a protease production medium and then incubated at $150 \mathrm{rpm}$ at $37^{\circ} \mathrm{C}$ for 16 hours (incubation timing for optimum protease activity). The culture was centrifuged at $9.820 \times g$ at $4^{\circ} \mathrm{C}$ for 15 minutes. The free-cell supernatant was used and partially purified by ammonium sulfate precipitation as described by Scopes, (1994). The crude protease (the free-cell supernatant) were partially purified by three levels of ammonium sulfate concentration ranges, $0-70 \%$, $70-75 \%$ and $75-80 \%$. The supernatant was slowly mixed with ammonium sulfate in a cold condition and then centrifuged at $12.100 \times g$ at $4^{\circ} \mathrm{C}$ for 20 minutes. The protein precipitate was dissolved in 50 $\mathrm{mM}$ Tris- $\mathrm{HCl}$ buffer $\mathrm{pH} 7.5$ and dialyzed against 20 $\mathrm{mM}$ Tris- $\mathrm{HCl}$ buffer with a $\mathrm{pH}$ of 7.5.

\section{Protein concentration and protease activity assay}

Protein concentration was assayed by the Bradford method (1976), while the protease activity was assayed as described by Anson, (1938). Protease activity assay was conducted using casein prepared in $20 \mathrm{mM}$ carbonate-bicarbonate buffer, while trypsin assay was conducted at $37^{\circ} \mathrm{C}$ using casein; prepared in $100 \mathrm{mM}$ Tris buffer. One unit of protease activity was defined as the amount of enzyme required to produce peptides equivalent to $1 \mu \mathrm{g}$ of tyrosine in the filtrate per minute per $\mathrm{ml}$. Similarly, one unit of trypsin activity was defined as the amount of enzyme required to produce peptides equivalent to $1 \mu \mathrm{g}$ of tyrosine in the filtrate per minute per $\mathrm{ml}$.

\section{Determination of molecular weight protease}

The protease molecular weight was determined using the SDS-PAGE technique as described by Laemmli (1970). Five microliters of protein marker (Page Ruler Unstained Protein Ladder) was used as an indicator to determine the molecular weight of the sample protein.

\section{Optimization of conditions}

The optimum condition was determined as described by Ghafoor and Hasnain, (2009). The protease activity was measured in different concentrations of $\mathrm{NaCl}(0-10 \%)$, with various metal ions (5 mM EDTA, $\mathrm{Ca}^{2+}, \mathrm{Cu}^{2+}, \mathrm{Fe}^{3+}, \mathrm{Mg}^{2+}, \mathrm{Ni}^{2+}$ and $\mathrm{Zn}^{2+}$ ions), varying $\mathrm{pH}$ levels $(4.0-12.0)$ and at different temperatures $\left(25-75^{\circ} \mathrm{C}\right)$.

\section{The effect of using SDS for protease activity}

The effect of SDS was measured by determining protease activity after an enzyme and substrate were mixed and incubated at various SDS concentrations $(0-10 \%)$ at optimum conditions for 30 minutes.

\section{RESULTS AND DISCUSSION}

\section{Screening of proteolytic activity}

The proteolytic potential of 5 halophilic isolates from the Bledug Kuwu mud crater was assayed by the agar diffusion (paper disc) method (Figure 1). The results showed that all five isolates have proteolitic ability on a solid medium and were observed as clear zones. Based on the results, it

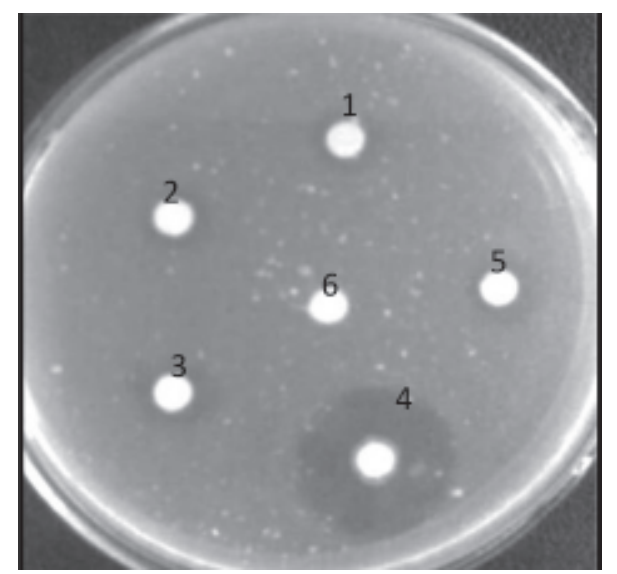

Fig. 1. Clear zone as proteolytic potential of five halophilic isolates from Bledug Kuwu mud crater, (1) Halomonas elongata $\mathrm{BK}-\mathrm{AB} 8$, (2) Halomonas meridiana BK-AB4, (3) Halomonas elongata BK-AG18, (4) Chromohalobacter japonicus BK-AB18, (5) Halomonas eurihalina BK-AB15 and (6) Control. 
appears that the clear zone around the disc of Chromohalobacter japonicus BK-AB18 supernatant was much larger than other isolates.

The growth and protease activity profile of Chromohalobacter japonicus BK-AB18

Based on the proteolytic screening, next, we used C. japonicus BK-AB18 as isolate to produce extracellular protease. The growth and protease activity profile of $C$. japonicus $\mathrm{BK}-\mathrm{AB} 18$ created the best incubation time for protease production. The OD and protease activity of the bacterial culture in the medium were measured continuously (Figure 2). The result showed that the highest extracellular protease activity from $C$. japonicus BK-AB18 was produced at the log phase of 16 hours of bacterial growth which was the highest peak of activity, as shown in the graphic. Based on this, the extracellular protease from C. japonicus BK-AB18 was harvested at 16 hours of inoculation time.

\section{Production and purification of protease}

The free-cell supernatant of bacterial culture was harvested and then partially purified by three levels of ammonium sulfate concentration. The partially purified protease results are shown in Table 1. All of the ammonium sulfate fractions had protease activity, but the highest specific activity was exhibited by the fraction of $75-80 \%$, which was 2129.98 Units/mg. A unit of protease activity is the amount of protease enzyme used to produce $1 \mathrm{mmol}$ of tyrosine (a product of casein hydrolysis) for every minute.

Based on the protease activity results shown in Table 1, the fraction of $75-80 \%$ was used for protease characterization. The molecular weight (MW) protease was measured by SDS-PAGE and the protease in this fraction had a relative MW of $65 \mathrm{kDa}$ (Figure 3). The extracellular protease was also isolated from the halophilic bacteria, Chromohalobacter sp. TVSP101 and had a relative MW of $66 \mathrm{kDa}$ (Vidyasagar et al., 2009).

\section{The optimum condition of protease activity}

The ammonium sulfate fraction of $75-80 \%$ from $C$. japonicus BK-AB18 was then characterized using biochemical parameters. The optimization of $\mathrm{NaCl}$ is very important because the bacteria used in

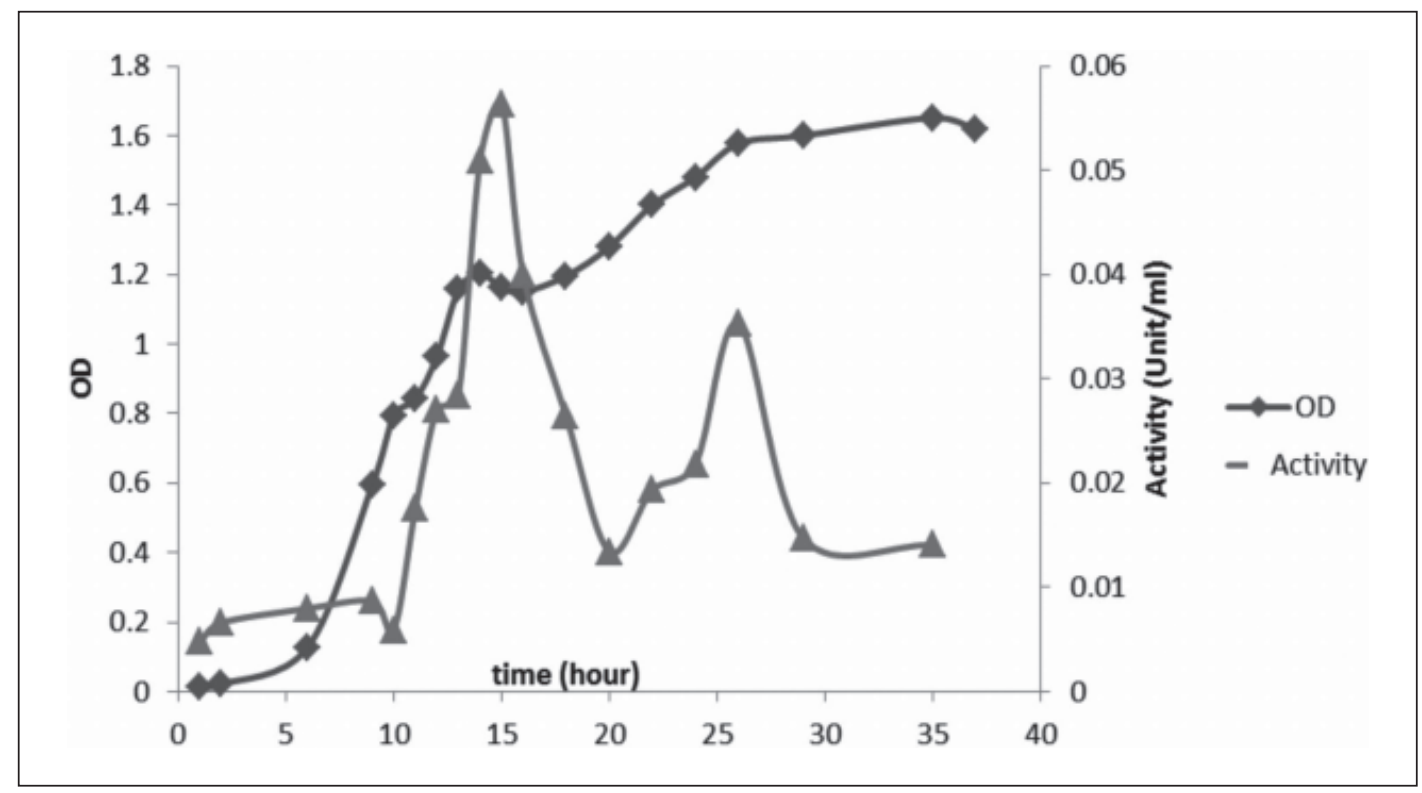

Fig. 2. Clear zone as proteolytic potential of five halophilic isolates from Bledug Kuwu mud crater, (1) Halomonas elongata BK-AB8, (2) Halomonas meridiana BK-AB4, (3) Halomonas elongata BK-AG18, (4) Chromohalobacter japonicus BK-AB18, (5) Halomonas eurihalina BK-AB15 and (6) Control.

Table 1. The result of ammonium sulfate precipitation of crude enzyme from $C$. japonicus BK-AB18

\begin{tabular}{ccccc}
\hline $\begin{array}{c}\text { Ammonium Sulfate } \\
\text { Precipitation }\end{array}$ & $\begin{array}{c}\text { Total Protein } \\
(\mathrm{mg})\end{array}$ & $\begin{array}{c}\text { Unit Activity } \\
\text { (Unit) }\end{array}$ & $\begin{array}{c}\text { Specific Activity } \\
\text { (Unit/mg) }\end{array}$ & $\begin{array}{c}\text { Purification } \\
\text { Factor }\end{array}$ \\
\hline Crude Enzyme & 12.29 & 1956.55 & 159.20 & 1 \\
$0-70 \%$ & 0.18 & 81.82 & 454.54 & 3 \\
$70-75 \%$ & 0.10 & 65.45 & 654.54 & 4 \\
$75-80 \%$ & 0.04 & 85.20 & 2129.98 & 13 \\
\hline
\end{tabular}




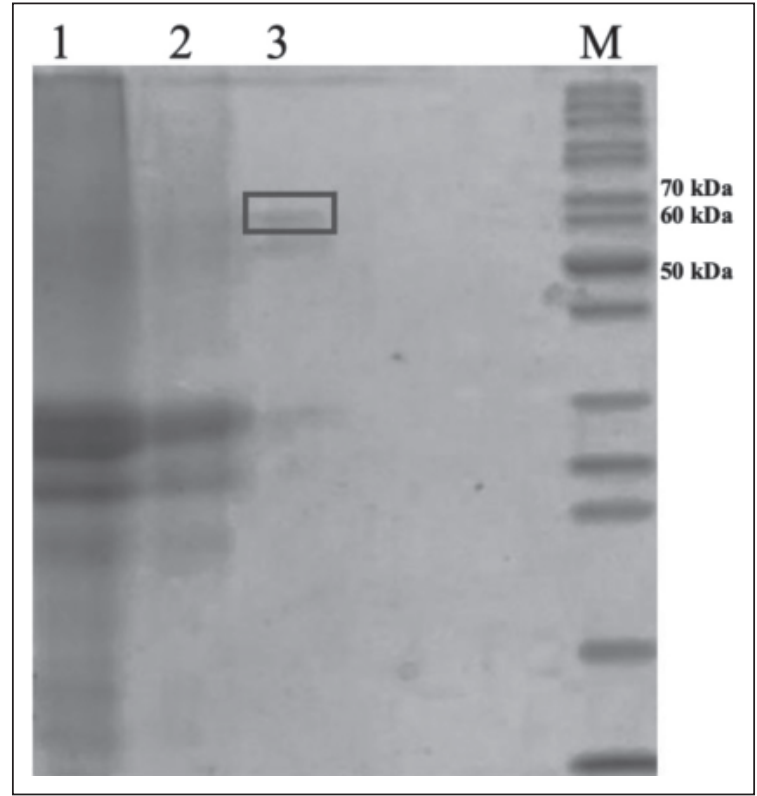

Fig. 3. The result of SDS-PAGE, the fraction of (1) 0 $70 \%$, (2) $70-75 \%$, (3) 75-80\%, and (M) Protein Marker.

this study are halophilic bacteria, and the enzyme stability and activity are strongly influenced by the $\mathrm{NaCl}$ concentration in their environment.
The results obtained showed that this protease has good stability at a low $\mathrm{NaCl}$ concentration (up to a $30 \% \mathrm{NaCl}$ concentration) but the highest activity was shown at a concentration of $7.5 \%$ $\mathrm{NaCl}$ (Figure 4). C. japonicus BK-AB18 itself is a halophilic bacterium that can grow well in a concentration of $5.0-22.5 \% \mathrm{NaCl}$ (Asy'ari et al., 2014). The optimum condition of $\mathrm{NaCl}$ was used to determine the effect of EDTA and metal ions (Figure 5). EDTA is an inhibitor of metalloprotease that creates an interaction (chelate) with a metal ion. Based on this assay, the protease activity from $C$. japonicus BK-AB18 was inhibited by EDTA. This shows that this protease is metalloprotease. The enzyme activity is highly affected by metal ions as a cofactor. Based on the assay of the effect of metal ions, we determined that $\mathrm{Fe}^{2+}, \mathrm{Zn}^{2+}$ and $\mathrm{Ni}^{2+}$ ions do not significantly affect protease activity. The protease activity can be increased by the addition of $\mathrm{Ba}^{2+}, \mathrm{Mg}^{2+}$ and $\mathrm{Ca}^{2+}$ ions. The activity is more significantly increased by the addition of $\mathrm{Ca}^{2+}$ ions than the addition of $\mathrm{Ba}^{2+}$ and $\mathrm{Mg}^{2+}$ ions.

The effects of $\mathrm{pH}$ and temperature were measured in two different conditions: a buffer solution with the addition of the $\mathrm{Ca}^{2+}$ ion and a buffer solution without the addition of the $\mathrm{Ca}^{2+}$ ion

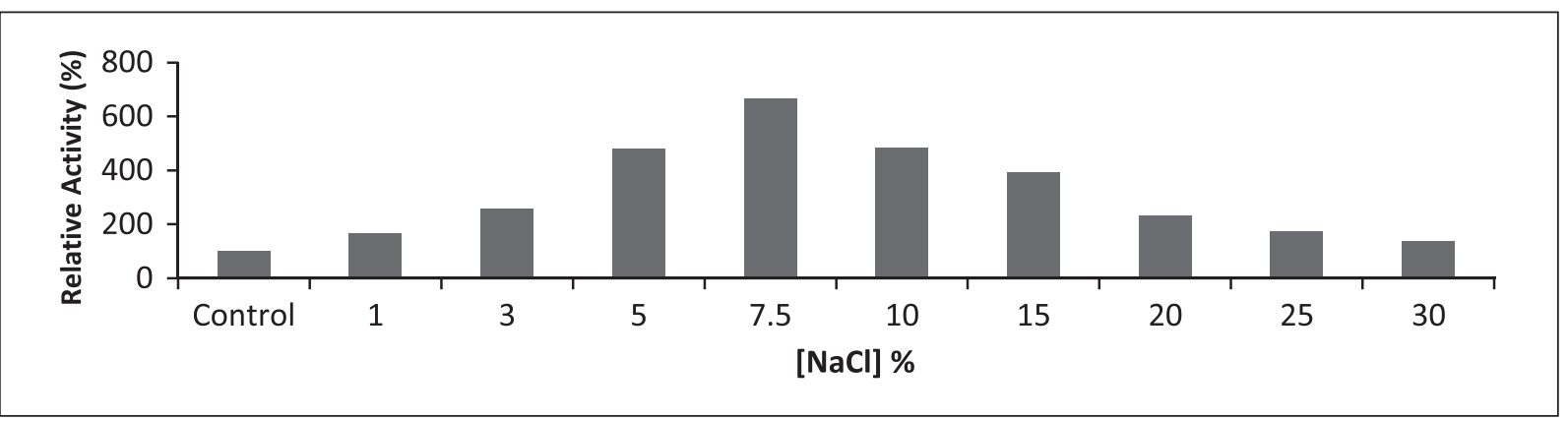

Fig. 4. The effect of various levels of $\mathrm{NaCl}$ concentration on protease activity.

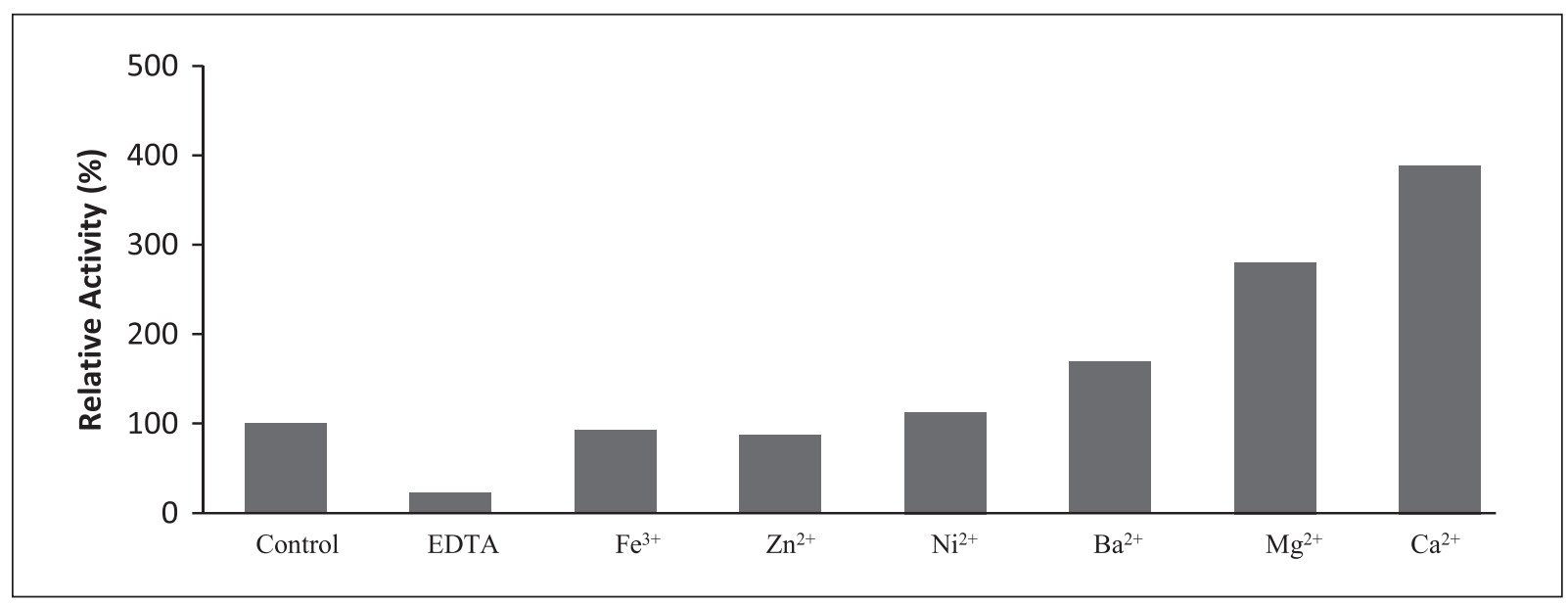

Fig. 5. The effect of EDTA and metal ions on protease activity. 
(Figure 6). The optimum $\mathrm{pH}$ at both conditions is $\mathrm{pH}$ 9.0, and therefore, this protease was classified as an alkaline protease. An alkaline protease has the potential to be applied in the detergent industry (Khan, 2013). The protease activity was significantly decreased at extreme $\mathrm{pH}$ levels, such as between $\mathrm{pH}$ 4.0 and 12.0 , because the sensitive site of protein molecules is generally uncharged residues and at an extreme $\mathrm{pH}$ will change conformation due to changes in the cargoof residues (Scope, 1994). The conformation improperly influences the binding of the substrate at the catalytic site and decreases protease activity. Based on the assay of the effect of $\mathrm{pH}$, the results show that the addition of a $\mathrm{Ca}^{2+}$ ion is able to increase the protease activity at all $\mathrm{pH}$ range variations $(4.0-12.0)$. This indicates that the $\mathrm{Ca}^{2+}$ ion is able to increase the stability of the protease structure. The result showed that the optimum temperature of this protease measured at the two different conditions is $45^{\circ} \mathrm{C}$ (Figure 7). The addition of $\mathrm{Ca}^{2+}$ ions can significantly improve protease activity at all temperature variations. The existence of a $\mathrm{Ca}^{2+}$ ion stabilizes the structure of the protease, allowing for good protease activity in a wide temperature range.

\section{The effect of SDS concentration on protease activity}

The effect of the SDS concentration on protease activity was assayed at the optimum conditions, as follows: $7.5 \% \mathrm{NaCl}$, the addition of $5 \mathrm{mM}$ of a $\mathrm{Ca}^{2+}$ ion, a $\mathrm{pH}$ level of 9.0 and a temperature of $45^{\circ} \mathrm{C}$ (Figure 8). At these conditions protease activity is optimum, allowing for the protease to be resistant in extreme environments, such as in a detergent or SDS solution. SDS is an ionic surfactant, which has both ionic hydrophobic and hydrophilic sides, so it can inhibit protease activity. The results of assaying the effect of various SDS concentrations showed that the protease from $C$. japonicus

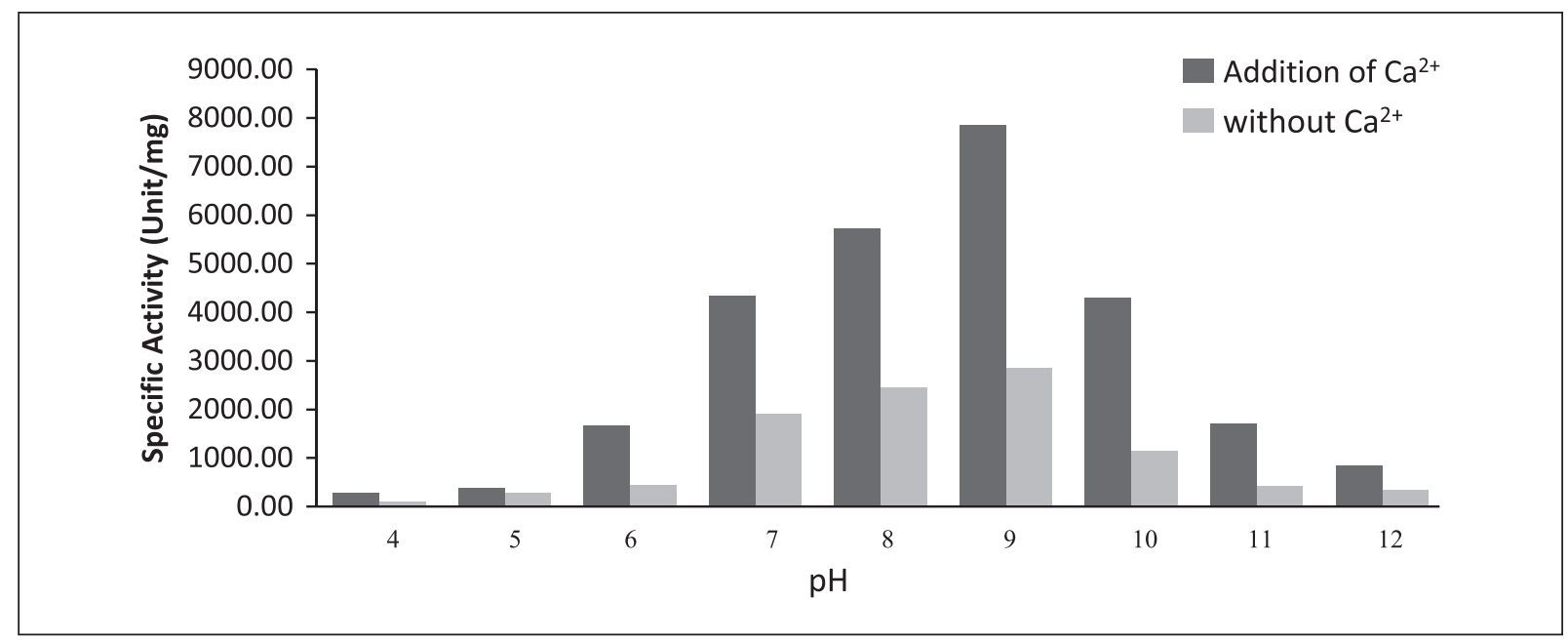

Fig. 6. The effect of $\mathrm{pH}$ to protease activity with added $\mathrm{Ca}^{2+}$ ions and without $\mathrm{Ca}^{2+}$ ion.

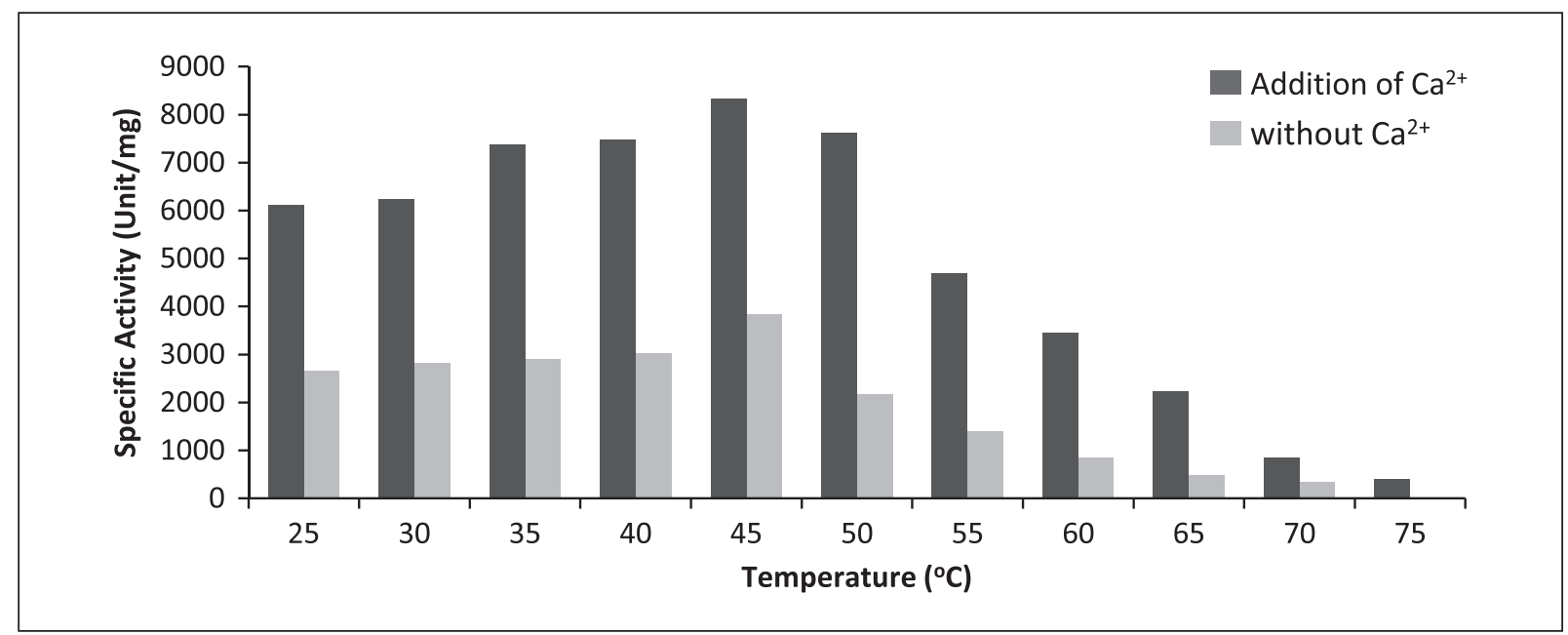

Fig. 7. The effect of various temperatures to protease activity at optimum $\mathrm{pH}$. 


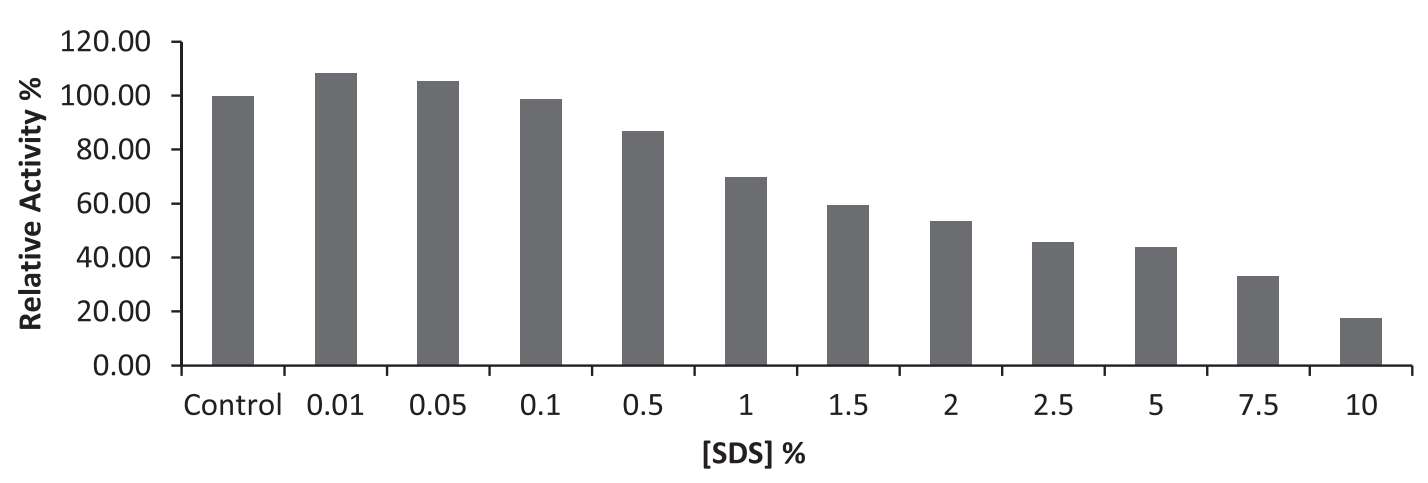

Fig. 8. The effect of various SDS concentrations at optimum condition to protease activity.

BK-AB18 has good stability in an SDS solution. The protease activity increased in low SDS concentrations $(0.01$ and $0.05 \%$ solutions $)$. This indicated that protease flexibility increased as an effect of hydrophobic interaction between the enzyme and the SDS molecules, and that interaction of enzyme intramolecular activity was decreased (Oberoi et al., 2001). The activity of protease was relatively stable in an SDS solution up to a concentration of $10 \%$. This showed that the protease in this fraction had high stability in the SDS solution.

\section{ACKNOWLEDGEMENT}

This work is funded by Priority Research Grant from Indonesian Ministry of Research and Technology with the contract number of $585 \mathrm{u} / 11 . \mathrm{C} 01 / \mathrm{PL} / 2016$.

\section{REFERENCES}

Anson, M.L. 1938. The estimation of pepsin, trypsin, papain, and cathepsin with hemoglobin. The Journal Gen Physiology, 22: 79-89.

Asy'ari, M., Parwata, I.P., Aditiawati, P., Akhmaloka \& Hertadi, R. 2014. Isolation and Identification of Halostable Lipase Producing Bacteria from the Bledug Kuwu Mud Crater Located at Purwodadi-Grobogan, Central Java, Indonesia. Journal of Pure and Applied Microbiology, 8(5): 3387-3396.

Bradford, M. 1976. A Rapid and Sensitive Method for The Quantization of Microgram Quantities of Protein utilizing The Principle of Protein-dye Binding. Analytical Biochemistry, 72: 248-254.

Ghafoor, A. \& Hasnain, A. 2009. Characterization of an Extracellular Protease Isolated from Bacillus subtilis AG1 and its Performance in Relation to Detergent Components. Annuals of Microbiology, 59(3): 559-563.
Gupta, R., Beg, Q.K. \& Lorenz, P. 2002. Bacterial Alkaline Protease: Molecular Approaches and Industrial Applications. Applied Microbiology Biotechnology, 59: 15-32.

Haddar, A., Kamun, A.S., Amidet, N. \& Nasri, M. 2009. Characterization of Deterjent Stable and Leather Degrading Serine Protease from Bacillus mojavensis A21. Biochemical Engineering Journal, 51(1-2): 53-63.

Khan, F. 2013. New Microbial Proteases in Leather and Detergent Industries. Innovative Research in Chemistry, 1(1): 1-6.

Laemmli. 1970. Clevage of Structural Protease during the Assembly of the Head of Bacteriophage T4. Nature, 227: 680-685.

Motyan, J.A., Toth, F. \& Tozser, J. 2013. Research Applications of Proteolytics Enzymes in Molecular Biology. Biomolecules, 3: 923-942.

Oberoi, R., Beg, Q.K., Puri, S., Saxena, R.K. \& Gupta, R. 2001. Characterization and Wash Performance Analysis of an SDS-stable Alkaline Protease from a Bacillus sp., World Journal of Microbiology and Biotechnology, 17: 493-497.

Rao, M.B., Tanksale, A.M., Chatge, M.S. \& Deshpade, V.V. 1998. Molecular and Biotechnological Aspects of Microbiol Proteases. Microbiol Molecular Biology Review, 62: $597-$ 635.

Scopes, R.K. 1994. Protein Purification: Principles and Practice Third Edition. Springer-Verlag, New York.

Sneha, S., Das, M.P. \& Rebecca, L.J. 2014. Isolation and Screening of Protease producing Bacteria from Marine Waste. Journal of Chemistry and Pharmaceutical Research, 6(5): 1157-1159.

Vidyasagar, M., Prakash, S., Mahajan, V., Shouche, Y.S. \& Sreeramulu, K. 2009. Purification and Characterization of An Extreme Halothermophilic Protease from A Halophilic Bacteria Chromohalobacter sp. TVSP101. Braz. Journal of Microbiology, 40: 12-17. 